DOI: $10.15593 / 2224-9354 / 2021.1 .3$

УДК 331.108 .44

\author{
Л.н. Банникова, А.С. Жилин
}

\author{
СОЦИАЛЬНОЕ САМОЧУВСТВИЕ МОЛОДЫХ \\ РАБОТНИКОВ ПРОМЫШЛЕННЫХ ПРЕДПРИЯТИЙ \\ И СТУДЕНТОВ: СРАВНИТЕЛЬНЫЙ АНАЛИЗ
}

\begin{abstract}
По материалам эмпирического исследования выполнен анализ социального самочувствия студентов, осваивающих инженерные программы подготовки, и молодых работников промышленных предприятий. В качестве пространства исследования выбраны шесть регионов с разным типом индустриального развития (от традиционных регионов с высоким уровнем промышленного производства до новых регионов с растущими высокотехнологичными производствами), с разным уровнем российского регионального инновационного индекса. Вторичный анализ социальных данных, таких как материалы официальной государственной и региональной статистики, данные статистических обследований и результаты социологического исследования, реализованного в рамках проекта, выявил отсутствие прямой взаимосвязи между уровнем социально-экономического развития регионов, отраженного в статистических показателях, и характером социальных настроений и ожиданий работающей и студенческой молодежи исследуемых регионов. Было установлено, что при сравнительно невысоких темпах модернизации территории могут наблюдаться средние и выше средних по массиву показатели удовлетворенности жизнью и уверенности в завтрашнем дне. Наряду с этим при сравнительно высоких показателях индекса инновационного развития в ряде регионов могут быть негативные социальные ожидания, пессимистические социальные настроения. Полученные результаты находят объяснение в концепции социального благополучия, подтверждая действие «парадокса Истерлина» в исследуемых российских регионах. Сравнительный анализ полученных данных позволил также сделать вывод о том, что территориальные различия в уровне социального самочувствия студенческой и работающей молодежи более значимы, чем отличия между отрядами студенческой молодежи и «молодыми взрослыми» одного региона.

Ключевые слова: социальное самочувствие, студенты, работающая молодежь, индустриальный регион.
\end{abstract}

Введение. Одним из достаточно чутких параметров, характеризующих социокультурный потенциал отдельных социальных групп и общества в целом, является социальное самочувствие людей. Для каждого конкретного человека его социальный настрой может быть оценен как показатель уровня удовлетворенности/неудовлетворенности своим социальным статусом, окружением [1-3]. Проявления социального самочувствия эмоциональны по своему характеру, сложно поддаются социальным измерениям. Вместе с тем как

() Банникова Л.Н., Жилин А.С., 2021

Банникова Людмила Николаевна - д-р социол. наук, профессор кафедры социологии и технологий государственного и муниципального управления ФГБОУ ВО «Уральский федеральный университет имени первого Президента РФ Б.Н. Ельцина», e-mail: urfu.bannikova@bk.ru.

Жилин Александр Сергеевич - канд.техн. наук, ведущий специалист по аналитической работе Центра развития инженерного образования, доцент кафедры фризико-химических методов анализа ФГБОУ ВО «Уральский федеральный университет имени первого Президента РФ Б.Н. Ельцина», e-mail: zh-al@yandex.ru. 
базовый элемент социального настроения самочувствие выполняет функцию регулятора социального поведения, оказывает влияние на формирование жизненной стратегии личности $[4,5]$. Исследование и оценки социального самочувствия, социальных ожиданий и жизненных планов молодых жителей отдельных регионов могут служить своеобразным барометром состояния общественного сознания в целом, выявлять реакцию населения на социальнополитические и экономические преобразования [6-8].

На предыдущем этапе (2018-2019 гг.) исследовательского проекта по изучению образа будущего и оценке инновационного потенциала молодых жителей шести российских регионов было установлено, что позитивное социальное самочувствие молодежи формирует «мотивирующее поле» для развития творческих идей, желания создавать и продвигать новые проекты, осваивать новации $[9,10]$. Объектом настоящего исследования стали учащиеся технических направлений подготовки вузов и ряда колледжей, своего рода «младшая» группа молодежи этих же шести российских регионов. Работающая молодежь, или «молодые взрослые» (25-35 лет), уже сделали свой профессиональный выбор, имеют определенную квалификацию, некоторый жизненный и профессиональный опыт. Для них первоначальное освоение профессии закончено, сейчас они наращивают квалификацию, растут по профессиональной и должностной лестнице. Для подавляющего большинства из них на первый план выходит потребность в самоутверждении, желание достичь независимости в своих действиях [11]. Для молодых людей свойственна готовность к адаптации, невысокий уровень сопротивления изменениям. Значительная их часть обладает креативным и нестандартным мышлением, они готовы разрабатывать и предлагать идеи. Инновационный потенциал работающей молодежи при определенных условиях может быть успешно использован, а может остаться невостребованным. Как было установлено ранее, в настоящий период фактическая реализация идей и проектов среди работающей молодежи исследуемых регионов невысока. В процессе исследования мы выяснили, что для молодых работников промышленных предприятий более характерна деятельность, связанная с освоением уже готовых новаций, наращиванием своего ресурсного потенциала, повышением образовательного или профессионально-квалификационного уровня. Зафиксирована низкая активность молодых работников в разработке и представлении своих творческих профессиональных и бизнес-проектов, а также незначительное участие в изобретательской и рационализаторской деятельности, в конкурсах на получение грантов и стипендий [9, с. 183-184].

Двойственность ситуации, в которой в настоящее время формируются социальные ожидания и социальные настроения студенческой молодежи индустриальных регионов, создает определенные сложности в их оценке. Молодежь студенческая в силу возраста и образования оценивается как высокоресурсная группа молодежи, а с другой стороны, это общность с более 
высокими, чем работающая молодежь рисками социализации, нестабильными перспективами трудоустройства, возможной жесткой конкуренцией за привлекательные рабочие места [12].

В настоящее время эти риски не только сохраняются, но и возрастают, многие из студентов в условиях пандемии уже потеряли работу. По данным опроса, работодатели очень неохотно сегодня принимают студентов, предпочитая удерживать опытных работников [13].

Социальное самочувствие в нашем исследовании интерпретируется через субъективную удовлетворенность молодого человека различными сторонами жизни. Удовлетворенность жизнью - это субъективная оценка индивидом его экономического и социального положения. По мнению ряда исследователей, существуют статистические подтверждения высокой взаимосвязи понятий «удовлетворенность жизнью» и «счастье» [14]. В характеристике соотносимости этих понятий мы придерживались подхода, сформулированного Р.Ф. Инглхартом, определившим счастье как «состояние благополучия, измеряемого двумя показателями. Первый - удовлетворенность как рациональное ощущение того, что происходящее соответствует ожиданиям. И второе - счастье как эмоциональное состояние. При этом удовлетворение и счастье суть не одно и то же, хоть и идут рука об руку» [15].

Методология. Основной целью является проведение сравнительного анализа социального самочувствия работающей и студенческой молодежи ряда индустриальных регионов с различным уровнем социально-экономического развития. В качестве пространства исследования выбраны шесть регионов разного типа индустриального развития. В выборке представлены традиционные индустриальные регионы, сохранившие свои позиции и высокий уровень промышленного производства (Республика Башкортостан, Калужская область), традиционные индустриальные регионы, для которых в последние годы характерен устойчивый процесс деиндустриализации (Свердловская область, Красноярский край) и регионы, которые в настоящее время активно наращивают высокотехнологичные производства (Пермский край, Волгоградская область). Внутри регионов эмпирическим исследованием была охвачена молодежь, обучающаяся в передовых учебных заведениях (университетах, колледжах), занятая на наиболее крупных и перспективных в плане развития высокотехнологичных производств, предприятиях соответствующих регионов. Опрос с помощью традиционного печатного варианта анкеты был проведен в мае сентябре 2018-2019 г. Применялась целевая квотная выборка, в качестве квотных признаков выступили курс и программы подготовки для учащейся молодежи, регион проживания и отрасль для работающей молодежи [9]. Комплексное исследование социального самочувствия работающей молодежи промышленных предприятий реализовано на основе системы эмпирических индикаторов: удовлетворенность жизнью в целом и уверенность в завтрашнем 
дне, удовлетворенность индивидуальной жизненной траекторией (состоянием здоровья, работой, полученным образованием и др.), оценка своих возможностей по изменению/сохранению своей жизненной ситуации.

Вторичный анализ социальных данных, таких как материалы официальной государственной и региональной статистики, данных статистических исследований Института статистических исследований и экономики знаний «Высшей школы экономики» [16], ежегодного мониторинга, реализуемого аналитиками Российской академии народного хозяйства и государственной службы при Президенте Российской Федерации (РАНХ и ГС) и Ассоциацией инновационных регионов России (АИРР) [17]. Для анализируемых регионов характерна неравномерность развития различных аспектов инновационных процессов, что нашло отражение в рейтинге российского регионального инновационного индекса (РРИИ): от 7-го места Свердловской области до 56-го места Волгоградского региона среди 85 субъектов Федерации.

Результаты исследования социального самочувствия работающей и студенческой молодежи индустриальных регионов. По данным нашего опроса, более $3 / 4$ всех молодых респондентов вполне удовлетворены жизнью (табл. 1). Для студенческой и работающей молодежи характерна позитивная субъективная оценка своего положения. Возраст, по данным исследователей, важный фактор, влияющий на уровень удовлетворенности жизнью. Молодые люди в странах с переходной экономикой счастливы в той же мере, что и в других странах [18]. Четверо из каждых пяти работающих респондентов в той или иной степени довольны своей жизнью (по массиву соотношение полностью и частично довольных почти одинаково). В целом по массиву «довольных» своей жизнью в девять раз больше, чем недовольных.

Таблица 1

Работающая и студенческая молодежь об удовлетворенности жизнью и уверенности в завтрашнем дне

\begin{tabular}{|l|c|c|c|c|}
\hline \multirow{2}{*}{ Вариант ответа } & \multicolumn{2}{|c|}{ Удовлетворенность жизнью } & \multicolumn{2}{c|}{ Уверенность в завтрашнем дне } \\
\cline { 2 - 5 } & Работающие & Учащиеся & Работающие & Учащиеся \\
\hline Да, вполне & 40 & 38 & 30 & 30 \\
\hline Скорее да & 42 & 39 & 40 & 34 \\
\hline Скорее нет & 8 & 11 & 16 & 18 \\
\hline Нет & 4 & 5 & 8 & 11 \\
\hline Затрудняюсь ответить & 6 & 7 & 6 & 7 \\
\hline
\end{tabular}

У студенческой молодежи только в пять раз больше оптимистических оценок. Более того, преобладают (в полтора раза чаще) отчасти довольные (см. табл. 1). Казалось, что должно быть иначе: чем моложе, тем счастливее. Но такая закономерность лишь у молодежи Калужской области (рис. 1). Оптимизм работающей молодежи связан с их социальным статусом состоявшихся 
профессионалов, с законченным первоначальным освоением профессии и наличием прогнозируемых перспектив профессионального и личностного роста. Более высокие показатели удовлетворенности жизнью у работающей и студенческой молодежи Пермского края и Республики Башкирия, Красноярского края (см. рис. 1).

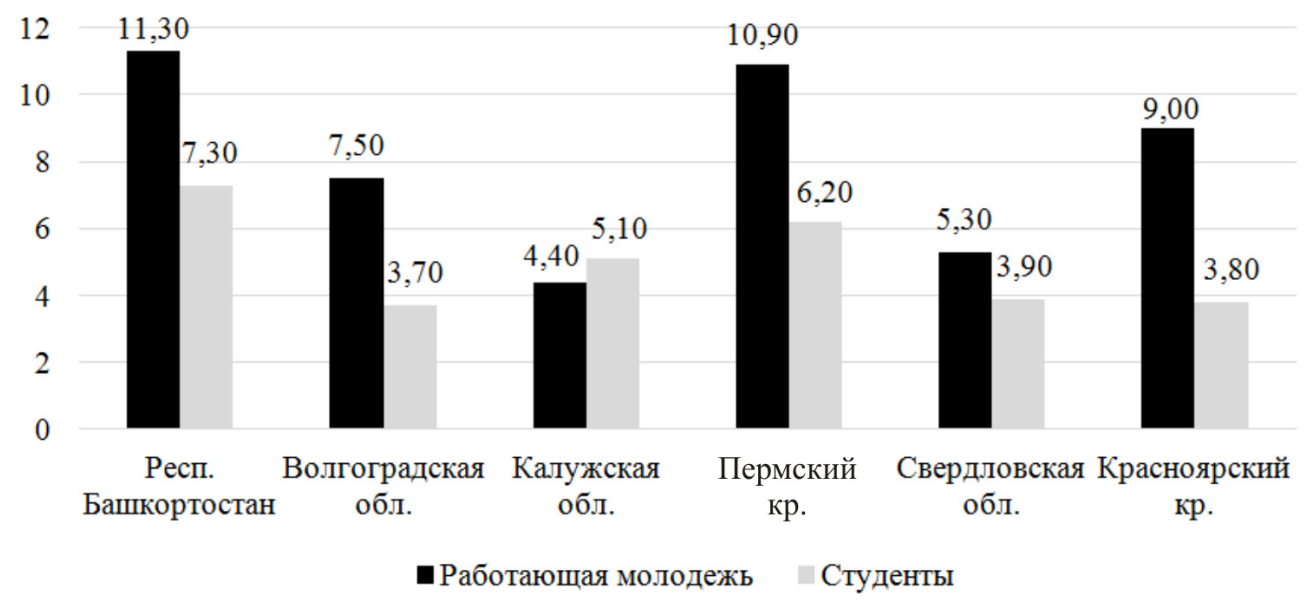

Рис. 1. Соотношение довольных («да», «скорее, да») и недовольных («скорее, нет», «нет») жизнью в целом (во сколько раз первых больше, чем вторых)

Выяснение зависимости удовлетворенности жизнью от уровня социальноэкономического развития регионов не позволило сделать однозначных выводов о наличии такой детерминационной связи. По уровню среднедушевых доходов населения лидирует Свердловская область (среднедушевой доход в 2018 г. 36,736 руб.) [19], а доля уверенных положительных ответов работающей молодежи области на вопрос о удовлетворенности жизнью наиболее низка (33 \% при 40 \% по массиву). Подобную закономерность несоответствия можно проследить и по ответам работающей молодежи Пермского края: по уровню среднедушевого дохода население территории на пятом месте среди исследуемых регионов, а по доле уверенных положительных ответов по удовлетворенности жизнью лидирует [9, с. 49]. Следует очень важный вывод о том, что рост материального благосостояния не обязательно приводит к росту удовлетворенности жизнью. Эта закономерность определена в современной экономической науке, в таком направлении исследований, как «экономика счастья», изучающего, как уровень удовлетворенности жизнью людей зависит от уровня доходов. Она получила название «парадокса Истерлина» в честь автора [20].

Наряду с оценкой общей удовлетворенности жизнью замерялось влияние социальных институтов. Оценка уровня их воздействия на социальное самочувствие это воздействие формальных элементов на неформальные составляющие институциональной среды. Если положительные оценки удовлетворенностью жизнью в 
целом у студентов достаточно высоки, то оценки положения дел в конкретных сферах общественной жизни, особенно в экономике, скорее удовлетворительные, чем хорошие, и более критичные, чем у работающей молодежи.

Показатели уверенности в завтрашнем дне в целом позитивны, но ниже уровня субъективной удовлетворенности жизнью. Семь из каждых десяти работающих и шесть из десяти студентов отметили, что ему (ей) присуща уверенность в завтрашнем дне как защита от рисков. Респонденты из числа молодых работников промышленных предприятий и студенты отвечали уклончиво, более часто это были ответы «скорее, чем вполне» уверены. Чаще других такая уверенность (по их самооценкам) характерна для работающих респондентов из Красноярского и Пермского краев (рис. 2). Работающая молодежь, или «молодые взрослые», смотрят в будущее более уверенно.

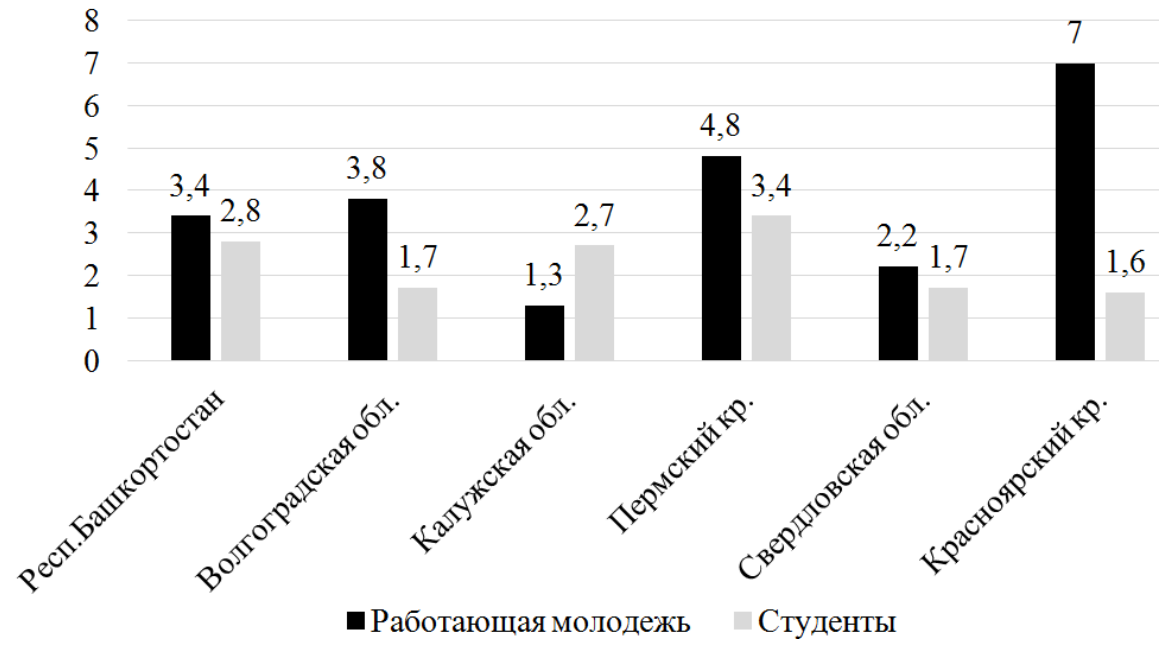

Рис. 2. Соотношение уверенных («да», «скорее, да») и неуверенных («скорее, нет», «нет») в завтрашнем дне (во сколько раз первых больше, чем вторых)

Сравнивая ценностные установки работающей и студенческой молодежи, нужно отметить общее признание семейного благополучия как основного критерия жизненного успеха. Ориентация на семейное счастье значима для $2 / 3$ студентов и $3 / 4$ работающей молодежи. Традиционалистская ориентация молодежи на приватную, частную жизнь, на семейное благополучие «может декорировать иные жизненные цели, в частности, связанные с карьерой и достатком, являясь проблемой личного выбора, но не проблемой реализации жизненных шансов» [21, с. 61]. Эта целевая ценностная установка доминирует в среднесрочном планировании студентами своих жизненных планов. Создать семью, родить ребенка, купить собственное жилье или улучшить жизненные условия у каждого второго респондента в планах на ближайшие пять лет (рис. 3 ). 
Свое дело, независимость от работодателя

Возможность заниматься творчеством, воплощать свои идеи

Карьера, достижение высоких должностных позиций

Собственное жилье

Высокие профессиональные достижения

Высокий экономический статус, уровень дохода

Хорошая семья, успешные дети

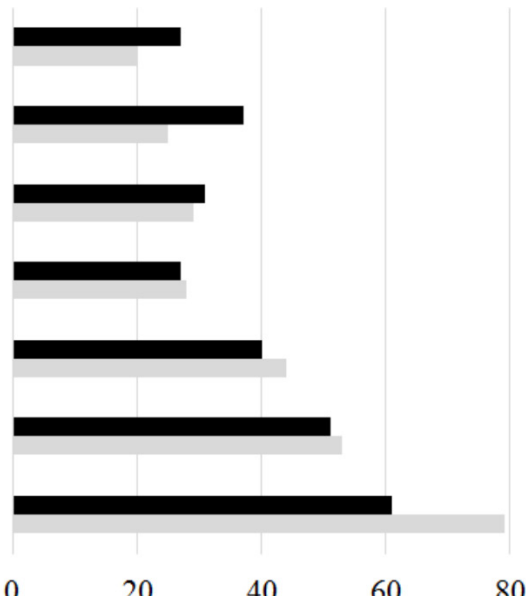

\section{шучащиеся Работающие}

Рис. 3. Жизненные стратегии работающей и студенческой молодежи

На втором месте у тех и других - материальное благополучие, высокий уровень доходов. Данный параметр, по справедливому замечанию исследователей, не свидетельствует ни в пользу традиционализма, ни в пользу достижительских ориентаций, поскольку подобное стремление может быть отражением как желания человека в материальном благополучии, состоятельности, так и быть мотиватором к достижению новых жизненных позиций, иного образа жизни [21, с. 63]. У 40-44 \% работающей и студенческой молодежи шести крупных индустриальных центров профессиональная самореализация декларируется в качестве критерия жизненного успеха. Еще для трети респондентов значима ориентация на должностное продвижение.

Социальная роль инженера предполагает наличие способности к инновациям, его творческие способности становятся своего рода «общественным ожиданием», входят в обязанность каждого, исполняющего роль независимо от того, кто конкретно исполняет эту роль [22, с. 440]. Возможность заниматься творчеством, воплощать свои идеи остается значимой ценностью для четверти работающих «технарей» и для более трети будущих инженеров. Такое направление инновационной активности, как предпринимательство, организация своего дела в планах у 20 \% работающей молодежи и у 27 \% студентов. Молодые люди в целом оценивают действия предпринимателей более позитивно, чем старшие поколения; чаще считают, что именно в бизнесе работают самые умные, талантливые и способные сограждане. По данным опросов исследователей, именно молодые россияне в два раза чаще, чем в среднем по выборке, говорят о желании открыть свое дело [23]. В нашей выборке открыть свое дело планирует в среднесрочной перспективе один из трех студентов и четверть из работающих респондентов. 
В оценке жизненных планов студентов и молодых работников промышленных предприятий территориальные различия не значимы. Нет различий между работающей и студенческой молодежью и в оценке инструментальных ценностей, кроме одного и весьма существенного отличия. Один из пяти студентов оценил высокий уровень профессионализма как способ достижения жизненных целей. Среди работающей молодежи такой выбор сделал каждый третий. Студенческая молодежь мало верит в профессионализм как гарант жизненного успеха. На вопрос о значимости в будущем работать по направлению подготовки, получаемой в вузе, колледже или техникуме только треть студентов всех шести регионов ответили, что это очень значимо и хотелось бы строить свою профессиональную карьеру в рамках выбранного направления подготовки. Еще треть заметили, что значимо это лишь отчасти, остальные сослались на обстоятельства, от чего будет зависеть их выбор будущей занятости.

В исследованиях профессионального самоопределения молодежи неоднократно отмечался процесс подмены выбора профессии выбором места ее получения, образовательного учреждения [12]. На наш взгляд, столь скромные оценки профессионализма (часто воспринимаемого не как накопление компетенций, а как развитие в рамках полученного формального образования) в качестве канала достижения жизненного успеха связано с тем, что сегодня профессиональное образование часто не служит стимулом успешной карьеры, но даже гарантом занятости.

Молодежь регионов в качестве способа достижения успеха в жизни рассчитывает, прежде всего, на упорный труд (табл. 2). Данные нашего опроса молодежи совпадают с оценками, полученными в опросе аналитиков ЛевадаЦентра, когда вариант ответа « чрезвычайно важно» и «очень важно» на вопрос о том важен ли упорный труд для успеха в жизни, выбрали почти 3/4 pecпондентов. Упорный труд для успеха важнее, чем качественное образование и полезные связи [24].

Таблица 2

Работающая и учащаяся молодежь о качествах и обстоятельствах, помогающих достичь успеха в жизни, \%

\begin{tabular}{|l|c|c|}
\hline \multicolumn{1}{|c|}{ Параметры оценки } & Учащиеся & Работающие \\
\hline Качественное образование & 35 & 38 \\
\hline Работоспособность, трудолюбие & 64 & 66 \\
\hline Стартовый капитал, деньги & 23 & 20 \\
\hline Связи, поддержка влиятельных родственников и друзей & 31 & 31 \\
\hline Амбиции, целеустремленность & 44 & 39 \\
\hline $\begin{array}{l}\text { Способность не обращать внимание на общественные устои, } \\
\text { мораль и нравственность }\end{array}$ & 9 & 7 \\
\hline Готовность рисковать & 22 & 17 \\
\hline Врожденные способности, таланты & 11 & 16 \\
\hline Высокий уровень профессионализма (профессиональной подготовки) & $\mathbf{2 1}$ & $\mathbf{3 1}$ \\
\hline Креативность, нестандартность мышления & 28 & 27 \\
\hline
\end{tabular}


Креативность, нестандартность мышления как ценность-средство, как способ достижения успеха в равной мере отметил каждый третий студент и «молодой» взрослый. Выбор подобных ценностей выступает своеобразным маркером формирования проинновационных установок и мышления. По данным исследования РБК, именно образованная молодежь (18-30 лет), проживающая в крупных городах, демонстрирует наиболее проинновационные установки. Например, 86 \% жителей России в возрасте 18-30 лет считают, что избегать новых ситуаций не следует, 92 \% из них считают, что предпринимательство - хороший карьерный выбор. Также жители крупных городов и молодые респонденты предсказуемо больше доверяют новейшим технологиям [25].

Заключение. Сравнительный анализ эмпирических данных позволил сделать вывод о том, что территориальные различия в уровне социального самочувствия студенческой и работающей молодежи более значимы, чем отличия между отрядами студенческой молодежи и «молодыми взрослыми» одного региона. Неравномерность развития социально-экономического пространства исследуемых регионов как фон повседневной жизни оказывает воздействие на формирование ценностных, в том числе и инновационных установок студенческой молодежи: на целеустремленность и амбиции, на готовность или нежелание рисковать, на оценку важности нестандартного мышления для успеха в жизни. В меньшей степени воздействие социально-экономических факторов сказывается на формировании таких характеристик, как горизонт планирования, навыки стратегического мышления, уровень институционального доверия. В свою очередь, подобные установки, формируя те или иные модели поведения, могут выступать как драйверами, так и барьерами для внедрения новых технологий, оказывать влияние на создание инноваций. Образную метафору роли социокультурных факторов приводят исследователи Института национальных проектов, сравнивая их со своего рода маленькой гирей на веcax, способной склонить чашу в одну или другую сторону, и неиспользование этой «гири», т.е. нежелание учитывать влияние социокультурных факторов, ведет к неэффективности и потерям общественного благосостояния [26, с. 19].

В исследовании и оценке инновационного потенциала такой высокоресурсной группы, как молодежь индустриальных регионов, нужно принимать во внимание не только статистические параметры развития социально-экономического пространства этих регионов, рейтинги университетов, но и доминирующие ценностные установки молодежи. Последние могут стать как стимулами, так барьерами формирования инновационного мышления, активности молодежи.

Статья подготовлена в рамках проекта «Молодежь индустриальных регионов России: образ сочиального будущего как фактор развития инновационного потеничила», реализуемого при поддержке Российского фонда фундаментальных исследований (РФФИ), грант № 18-011-00907/20. 


\section{Список литературы}

1. Петрова Л.Е. Социальное самочувствие молодежи //Социологические исследования. -2000 . - № 12. - С. 50-55.

2. Горшков М.К. Российское общество как оно есть (опыт социологической диагностики). - М.: Новый хронограф, 2011. - 672 с.

3. Степанов А.М. Сравнительный анализ социального самочувствия студентов высших и средних специальных учебных заведений// Вестник СПбГУ. Cер. 12. - 2016. - Вып. 2. - С. 47-59.

4. Карамельский Р.В. Проблемы измерения социального самочувствия // Вестник Чувашского университета. - 2011. - № 4. - С. 178-182.

5. Крупец Я.Н. Социальное самочувствие как интегральный показатель адаптированности // Социологические исследования. - 2003. - № 4. - С. 143-144.

6. Ефлова М.Ю., Ишкинеева Ф.Ф., Фурсова В.В. Социальное самочувствие и ценностные ориентации студенческой молодежи в контексте социальных изменений // Вестник Института социологии. - 2014. - № 10. - С. 34-44.

7. Образ будущего в оценках нового поколения россиян: моногр. / В.В. Гаврилюк, Л.Л. Мехришвили, Н.И. Скок [и др.]; Тюм. индустр. ун-т. Тюмень, 2016. - $166 \mathrm{c}$.

8. Социальное самочувствие молодежи регионов России: моногр. / Л.А. Саенко, А.Р. Тузиков, Р.И. Зинурова, С.А. Алексеев [и др.]. - Казань: Изд-во КНИТУ, 2017. - 148 с.

9. Молодежь индустриальных регионов России: образ социального будущего и инновационный потенциал: моногр. / Я.В. Дидковская, Л.Н. Банникова, Л.Н. Боронина, Ю.Р. Вишневский, К.М. Ольховиков, Д.В. Трынов. - Екатеринбург: Изд-во УрФУ, 2018. - 215 с.

10. Дидковская Я.В., Трынов Д.В. Социальное самочувствие и ожидания молодежи индустриального региона // Экономические и социальные перемены: факты, тенденции, прогноз. - 2019. - Т. 12, № 1. - С. 202-214.

11. Петрова Л.Е. Молодые взрослые: типология стратегий совладания с жизненными трудностями/Вестник Южно-Уральского государственного университета. Социально-гуманитарные науки. - 2006. - № 2 (57). - С. 208-211.

12. Студент 1995-2016 гг.: динамика социокультурного развития студенчества Среднего Урала: моногр. / Л.Н. Банникова [и др.]; под ред. Ю.Р. Вишневского. - Екатеринбург: Изд-во УрФУ, 2017. - 904 с.

13. Варсегова Н. Выпускники эпохи пандемии рискуют стать поколением безработных [Электронный ресурс] // Комсомольская правда. - 2020. - 7 июня. URL: https://www.ural.kp.ru/daily/27139.5/4231774/ (дата обращения: 11.12.20200).

14. Чинакова Н.В. Экономика счастья: современные исследования и дискуссии // Мир экономики и управления. - 2016. - Т. 16, № 1. - С. 101-115. 
15. Инглхарт Р.Ф. Очень хорошее будущее вполне вероятно. [Электронный ресурс]. - URL: https://www.hse.ru/news/science/165242865.html (дата обращения: 10.12.2020).

16. Рейтинг инновационного развития субъектов Российской Федерации [Электронный ресурс] / Г.И. Абдрахманова, С.В.Артемов, П.Д. Бахтин [и др.]; под ред. Л.М. Гохберга. - Вып. 6. - М.: Изд. дом НИУ ВШЭ, 2020. - URL: https://issek.hse.ru/rirr2019 (дата обращения: 10.12.2020).

17. Высокотехнологичный бизнес в регионах России.Национальный доклад 2020 [Электронный ресурс] / РАНХиГС, АИРР; под ред. С.П. Земцова. M., 2020. - URL: http://i-regions.org/upload/iblock/581/Hi_Tech_all_view.pdf (дата обращения: 10.12.2020).

18. Инглхарт Р.Ф. Счастья в России стало больше, но не для всех // Экспертный сайт Высшей школы экономики. - URL: http://opec.ru/1439744.html (дата обращения: 10.12.2020).

19. Регионы России. Социально-экономические показатели. Приложение к сборнику [Электронный ресурс] / Федер. служба гос. статистики. - URL: https://rosstat.gov.ru/folder/210/document/47652 (дата обращения: 11.12.2020).

20. Easterlin R.A. Does economic growth improve the human lot? Some empirical evidence // Nations and Households in Economic Growth. - N. Y., 1974. - P. 89-125.

21. Реутов Е.В., Реутова М.Н., Шавырина И.В. Жизненный успех и шансы на его достижение впредставлениях жителей российской провинции // Социологические исследования. - 2020. - № 6. - С. 61-71.

22. Штомпка П. Социология. Анализ современного общества. - М.: Логос, 2010. - 664 c.

23. Гражданский активизм российской молодежи [Электронный ресурс]: аналит. отчет / Левада-Центр. - URL: https://www.levada.ru/2020/10/01/ grazhdanskij-aktivizm-rossijskoj-molodezhi/ (дата обращения: 11.12.2020).

24. Общественное мнение - 2019. Ежегодник [Электронный ресурс] / Аналит. центр Юрия Левады (Левада-Центр). - URL: https://www.levada.ru/cp/ wp-content/uploads/2020/02/OM-2019.pdf (дата обращения: 12.12.2020).

25. Социокультурные факторы инновационной активности населения: [исследовательский отчет]/ Е.В. Антонов [и др.]; Ин-т нац. проектов; Рос. венч. компания. - М., 2019. - 124 с.

26. Социокультурные факторы инновационного развития и успешной имплементации реформ: [исследовательский отчет] [Электронный ресурс] / A.А. Аузан [и др.]; Ин-т нац. проектов. - M., 2017. - URL: https:/www.csr.ru/ uploads/2017/10/report-sf-2017-10-12.pdf (дата обращения: 11.12.2020).

\section{References}

1. Petrova L.E. Sotsial'noe samochuvstvie molodezhi [Social well-being of young people]. Sociological Studies, 2000, no. 12, pp. 50-55. 
2. Gorshkov M.K. Rossiiskoe obshchestvo kak ono est' (opyt sotsiologicheskoi diagnostiki) [Russian society as it is (experience of sociological diagnostics)]. Moscow, Novyi-Khronograf, 2011, 672 p.

3. Stepanov A.M. Sravnitel'nyi analiz sotsial'nogo samochuvstviia studentov vysshikh i srednikh spetsial'nykh uchebnykh zavedenii [Comparative analysis of student's subjective well-being in vocational and tertiary educational institutions of St. Petersburg]. Vestnik of Saint-Petersburg University. Sociology, 2016, no. 2, pp. $47-59$.

4. Karamel'skii R.V. Problemy izmereniia sotsial'nogo samochuvstviia [Problems of social well-being measurement].Vestnik Chuvashskogo universiteta, 2011, no. 4, pp. 178-182.

5. Krupets Ia.N. Sotsial'noe samochuvstvie kak integral'nyi pokazatel' adaptirovannosti [Social well-being as an integral indicator of adaptability]. Socioligical Studies, 2003, no. 4, pp. 143-144.

6. Eflova M.Iu., Ishkineeva F.F., Fursova V.V. Sotsial'noe samochuvstvie i tsennostnye orientatsii studencheskoi molodezhi v kontekste sotsial'nykh izmenenii [Student's social well-being and values in the context of social changes]. Bulletin of the Institute of Sociology, 2014, no. 10, pp. 34-44.

7. Gavriliuk V.V., Mekhrishvili L.L., Skok N.I. et al. Obraz budushchego v otsenkakh novogo pokoleniia rossiian [The image of future from the Russian new generation's perspective]. Tuymen, Industrial University of Tyumen, 2016, $166 \mathrm{p}$.

8. Saenko L.A., Tuzikov A.R., Zinurova R.I., Alekseev S.A. et al. Sotsial'noe samochuvstvie molodezhi regionov Rossii [Social well-being of young people in Russian regions]. Kazan, Kazan National Research Technological University, 2017, $148 \mathrm{p}$.

9. Didkovskaia Ia.V., Bannikova L.N., Boronina L.N., Vishnevskii Iu.R., Ol'khovikov K.M., Trynov D.V Molodezh' industrial'nykh regionov Rossii: obraz sotsial'nogo budushchego i innovatsionnyi potentsial [Youth of Russian industrial regions: The image of a social future and innovative potential]. Yekaterinburg, Ural Federal University, 2018, $215 \mathrm{p}$.

10. Didkovskaia Ia.V., Trynov D.V. Sotsial'noe samochuvstvie i ozhidaniia molodezhi industrial'nogo regiona [Social well-being and expectations of young people in the industrial region]. Economic and Social Changes: Facts, Trends, Forecast, 2019, vol. 12, no. 1, pp. 202-214.

11. Petrova L.E. Molodyevzroslye: tipologiia strategii sovladaniia $\mathrm{s}$ zhiznennymi trudnostiami [Young adults: The typology of the strategy struggle with vital difficulties]. Bulletin of South Ural State University. Humanities and Social Sciences, 2006, no. 2 (57), pp. 208-211.

12. Bannikova L.N. et al. Student 1995-2016 gg.: dinamika sotsiokul'turnogo razvitiia studenchestva Srednego Urala [Student 1995-2016: dynamics of socio- 
cultural development of students in the Middle Urals]. Ed. Iu.R Vishnevskii. Yekaterinburg, Ural Federal University, 2017, 904 p.

13. Varsegova N. Vypuskniki epokhi pandemii riskuiut stat' pokoleniem bezrabotnykh [Pandemic graduates run chances to become a generation of unemployed]. Komsomol'skaia pravda, 07.06.2020, available at: https://www.ural.kp.ru/ daily/27139.5/4231774/ (accessed 11.12.2020).

14. Chinakova N.V. Ekonomika schast'ia: sovremennye issledovaniia I diskussii [Economics of happiness: Current research and discussion]. World of Economics and Management, 2016, vol. 16, no. 1, pp. 101-115.

15. Inglkhart R.F. Ochen' khoroshee budushchee vpolne veroiatno [A very good future is a distinct possibility]. Available at: https://www.hse.ru/news/science/165242865.html (accessed 10.12.2020).

16. Abdrakhmanova G.I., Artemov S.V., Bakhtin P.D. et al. Reiting innovatsionnogo razvitiia sub"ektov Rossiiskoi Federatsii. Vypusk 6 [Innovative development rating of subjects in the Russian Federation. Issue 6]. Ed. L.M Gokhberg. Moscow, HSE, 2020, available at: https://issek.hse.ru/rirr2019 (accessed 10.12.2020).

17. Vysokotekhnologichnyi biznes $\mathrm{v}$ regionakh Rossii. Natsional'nyi doklad 2020 [High-tech business in Russian regions. National report 2020]. Ed. S.P. Zemtsov. Moscow, RANEPA, AIRR, 2020, available at: http://i-regions.org/upload/ iblock/581/Hi_Tech_all_view.pdf (accessed 10.12.2020).

18. Inglkhart R.F. Schast'ia v Rossii stalo bol'she, no ne dlia vsekh [There is more happiness in Russia, but not for everyone]. HSE, available at: http://opec.ru/1439744.html (accessed 10.12.2020).

19. Regiony Rossii. Sotsial'no-ekonomicheskie pokazateli. Prilozhenie k sborniku [Regions of Russia. Socio-economic indicators. Appendix to the collection]. Federal State Statistic Service, available at: https://rosstat.gov.ru/folder/ 210/document/47652 (accessed 11.12.2020).

20. Easterlin R.A. Does economic growth improve the human lot? Some empirical evidence. Nations and Households in Economic Growth, N.Y., 1974, pp. 89-125.

21. Reutov E.V., Reutova M.N., Shavyrina I.V. Zhiznennyi uspekh i shansy na ego dostizhenie $\mathrm{v}$ predstavleniiakh zhitelei rossiiskoi provintsii [Life success and chances for its achievement in the representations of the inhabitants of the Russian province]. Sociological Studies, 2020, no. 6, pp. 61-71.

22. Sztompka P. Socjologia. Analiza społeczeństwa (Russ. ed.: Shtompka P. Sotsiologiia. Analiz sovremennogo obshchestva. Moscow, Logos, 2010, 664 p.).

23. Grazhdanskii aktivizm rossiiskoi molodezhi [Civic activism of Russian youth]. Levada Tsentr, 01.10.2020, available at: https://www.levada.ru/2020/ 10/01/grazhdanskij-aktivizm-rossijskoj-molodezhi/ (accessed 11.12. 2020).

24. Obshchestvennoe mnenie 2019 [Public opinion 2019]. Levada Tsentr, 2020, available at: https://www.levada.ru/cp/wp-content/uploads/2020/02/OM2019.pdf (accessed 12.12.2020). 
25. Antonov E.V. et al. Sotsiokul'turnye factory innovatsionnoi aktivnosti naseleniia [Socio-cultural factors of population innovative activity]. Moscow, Institute of national projects, Russian venture company, 2019, $124 \mathrm{p}$.

26. Auzan A.A. et al. Sotsiokul'turnye factory innovatsionnogo razvitiiai uspeshnoi implementatsii reform [Sociocultural factors of innovative development and successful implementation of reforms]. 2017, Moscow, Nes, Institute of national projects, available at: https://www.csr.ru/uploads/2017/10/report-sf-2017-10-12.pdf (accessed 11.12.2020).

Оригинальность $78 \%$

Получено 15.12.2020 Принято 11.01.2021 Опубликовано 31.03.2021

\author{
L.N. Bannikova, A.S. Zhilin
}

SOCIAL WELL-BEING OF YOUNG INDUSTRIAL WORKERS AND STUDENTS: A COMPARATIVE ANALYSIS

The paper investigates the social well-being of students majoring in engineering and young employees of industrial enterprises on the basis of empirical research. The research scope embraces six regions with different types of industrial development and different levels of the Russian regional innovation index (RRII) - from traditional regions with a high level of industrial production to new regions with growing hightech industries. Secondary analysis of social data, such as official national and regional statistics, statistical survey data, and the results of a sociological study within the project have revealed no direct relationship between the level of socio-economic development of the regions expressed in statistical indicators and the nature of social attitudes and expectations of young workers and students in the regions concerned. It has been found that relatively low rates of modernization in some areas are accompanied by average and above average indicators of life satisfaction and confidence in the future. On the contrary, relatively high indicators of the innovation development index in certain regions are coupled with negative social expectations and pessimistic social moods. The results obtained are interpreted through the concept of social well-being, confirming the effect of the Easterlin Paradox in the Russian regions. A comparative analysis of the data also allowed us to conclude that territorial differences in the level of social well-being of young employees and students are more significant than those between groups of students and 'young adults' of the same region.

Keywords: social well-being, students, young workers, industrial region.

Lyudmila N. Bannikova - Doctor of Sociology, Professor, Department of Sociology and Technology of Public and Municipal Administration, Ural Federal University named after first President of Russia B.N. Yeltsin, Yekaterinburg, e-mail: urfu.bannikova@bk.ru.

Alexandr S. Zhilin - Cand. Tech. Sciences, Leading Specialist for the Analytical Work at the Center of Engineering Education Development; Associate Professor, Physico-Chemical Methods of Analysis Department, Ural Federal University named after the first President of Russia B.N. Yeltsin, Yekaterinburg, e-mail: zh-al@yandex.ru.

Received 15.12.2020 Accepted 11.01.2021 Published 31.03.2021 